\title{
Characterization of the in vitro Activities of the P1 and Helper Component Proteases of Soybean mosaic virus Strain G2 and Tobacco vein mottling virus
}

\author{
Hyoun-Sub Lim ${ }^{1}$, Chan-Yong Jang ${ }^{1}$, Jiryun Nam ${ }^{1}$, Meijia Li ${ }^{1}$, Jin-Sung Hong ${ }^{2}$, Hanhong Bae ${ }^{3}$, Ho-Jong Ju', \\ Hong Gi Kim ${ }^{1}$, Richard E. Ford ${ }^{5}$ and Leslie L. Domier ${ }^{5,6 *}$ \\ ${ }^{1}$ Department of Applied Biology, Chungnam National University, Daejeon 305-764, Korea \\ ${ }^{2}$ Institute of Natural Sciences, Seoul Woman's University, Seoul 139-774, Korea \\ ${ }^{3}$ School of Biotechnology, Yeungnam University, Geongsan 712-749, Korea \\ ${ }^{4}$ Department of Agricultural Biology, Chonbuk National University, Jeonju 561-756, Korea \\ ${ }^{5}$ Department of Crop Sciences, University of Illinois, Urbana, IL 61801, USA \\ ${ }^{6}$ United States Department of Agriculture-Agricultural Research Service, Urbana, IL 61801, USA
}

(Received on February 28, 2012; Revised on April 30, 2012; Accepted on April 30, 2012)

Potyviruses express their RNA genomes through the production of polyproteins that are processed in host cells by three virus-encoded proteases. Soybean plants produce large amounts of protease inhibitors during seed development and in response to wounding that could affect the activities of these proteases. The in vitro activities of two of the proteases of Soybean mosaic virus (SMV) and Tobacco vein mottling virus (TVMV) were compared in the rabbit reticulocyte lysate in vitro translation system using synthetic RNA transcripts. Transcripts produced from SMV and TVMV cDNAs that included the P1 and helper component-protease (HCPro) coding regions directed synthesis of protein products that were only partially processed. Unprocessed polyproteins were not detected from transcripts that included all of the P1, HC-Pro, P3 and portions of the cylindrical inclusion protein coding regions of either virus. Addition of soybean trypsin inhibitor to in vitro translation reactions increased the accumulation of the unprocessed polyprotein from TVMV transcripts, but did not alter the patterns of proteins produced from SMV. These experiments suggest that SMV- and TVMVencoded proteases are differentially sensitive to protease inhibitors.

Keywords : Helper-component protease, in vitro translation, P1 protease, trypsin inhibitor

Viruses in the family Potyviridae, the largest family of plant viruses (Adams et al., 2012), cause serious economic losses in numerous food and ornamental crops. Potyviruses have single-stranded positive-sense RNA genomes of approxi-

\footnotetext{
*Corresponding author.

Phone) +1-217-333-0510, FAX) +1-217-333-9817

E-mail) leslie.domier@ars.usda.gov
}

mately $10 \mathrm{~kb}$ and produce one large polyprotein of approximately $350 \mathrm{kDa}$ that is proteolytically processed to form individual functional proteins (Adams et al., 2012). The carboxyl-terminal two thirds of potyvirus polyproteins are cleaved by a virus-encoded protease, designated nuclear inclusion a (NIa) (Carrington and Dougherty, 1987), which functions similarly to the $3 \mathrm{C}$ proteases of animal picornaviruses (Adams et al., 2005). Potyviruses express two other proteases, P1 and helper component protease (HC-Pro), which catalyze cleavage at their own carboxyl-termini. P1 protease is a serine protease, and HC-Pro is classified as a papain-like cysteine protease (Adams et al., 2005). The Gly-Gly cleavage sites at the carboxyl-termini of HC-Pros are conserved among potyviruses. The cleavage sites at the carboxy-termini of $\mathrm{P} 1$ protease are less well conserved, but cleavages occur most commonly between Phe-Ser and TrySer dipeptides (Adams et al., 2005).

Soybean mosaic virus (SMV) and Tobacco vein mottling virus (TVMV) are both members of the family Potyviridae and have relatively narrow host ranges. SMV infects mainly soybean (Glycine max (L.) Merr.) and has been shown experimentally to infect at least 10 additional plant species, mostly in the family Fabaceae (Hill, 1999). In addition to tobacco (Nicotiana tobacum L.), TVMV has been shown to infect eight other plant species, mostly in the family Solanaceae (Sun et al., 1974).

Soybean seeds contain high levels of two classes of protease inhibitors, soybean trypsin inhibitor and BowmanBirk inhibitor, both of which inhibit serine proteases, and can represent up to $6 \%$ of the mass of mature soybean seeds (Laskowski and Kato, 1980). The soybean trypsin inhibitor gene is expressed early in soybean seed development (Walling et al., 1986). After germination, the levels of both classes of protease inhibitors decline during seedling growth and are only detected in cotyledons of mature plants (Tan- 
Wilson et al., 1985). In mature soybean plants, protease inhibitors can be induced in response to insect predation (Koiwa et al., 1997). In addition to soybean trypsin inhibitor, soybean plants induce cysteine protease inhibitors, phytocystatins, in response to wounding that inhibit papain-like digestive enzymes (Botella et al., 1996).

In these experiments, we tested the hypothesis that protease inhibitors that are expressed during soybean seed development and persist during germination and early seedling development differentially affect the activities of potyvirus-encoded proteases. This hypothesis was based on observations that SMV, as a seed-transmitted virus (Hill, 1999), must function in the tissues of young germinating seedlings that contain high levels of protease inhibitors, and that the P1 protease of TVMV cleaves autocatalytically in the wheat germ in vitro translation system, but not in the rabbit reticulocyte system, which was attributed to the presence of protease inhibitor(s) in rabbit reticulocyte lysates (Gopinath and Rhoads, 1991).

To test the hypothesis, we compared in vitro translation products synthesized in the rabbit reticulocyte lysate translation system programmed with in vitro transcripts from SMV or TVMV cDNA templates. In vitro transcripts were synthesized from restriction enzyme-cleaved full-length cDNA clones of SMV (pALE53, kindly provided by Dr. John Hill, Iowa State Univ.) and TVMV (pXBSIN) (Domier et al., 1989) that had been cleaved with BamHI at nucleotide positions 2319 and 1933, respectively. Transcripts were synthesized using bacteriophage T7 RNA polymerase and $500 \mathrm{ng}$ linearized plasmid DNA templates as recommended by the manufacturer (Promega, Madison, WI, USA). The transcripts included $\mathrm{P} 1$ and HC-Pro coding regions of SMV and TVMV (Fig. 1, A and B) and were translated in the rabbit reticulocyte lysate in vitro translation system (Promega) in the presence of $\mathrm{S}^{35}$ methionine (Dupont, Boston, MA, USA) as recommended by the manufacturer. Radioactively labeled proteins were analyzed on $8 \%$ polyacrylamide SDS gels. Protein bands were detected by exposing dried gels to X-ray film (Biomax, Kodak, Rochester, NY, USA) for 12-24 hr. The BamHI transcripts of SMV produced protein bands of about 35,43 and $80 \mathrm{kDa}$ on polyacrylamide gels. The $80-\mathrm{kDa}$ protein band corresponded to the expected size of the unprocessed product (Fig. 1C, lane 2). The $35-$ and $43-\mathrm{kDa}$ products may have been derived from proteolytic processing of the $80-\mathrm{kDa}$ protein and could represent $\mathrm{P} 1$ and HC-Pro, respectively. A strong band of about $70 \mathrm{kDa}$ appeared in the in vitro translations of the BamHI transcripts of TVMV corresponding to the expected size of the unprocessed translation product (Fig. $1 \mathrm{C}$, lane 3). In addition, lesser amounts of proteins of approximately 38, 50, 60, and $84 \mathrm{kDa}$ were observed (Fig. $1 \mathrm{C}$, lane 3$)$. Hence, neither of the amino terminal poly-

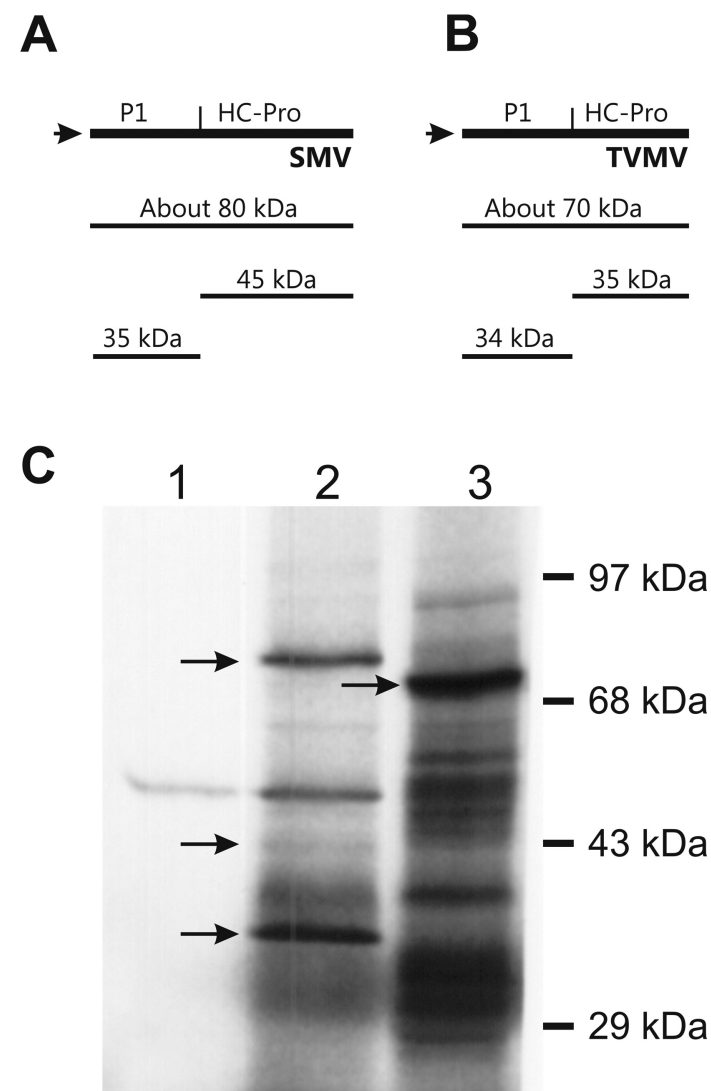

Fig. 1. Schematic representation of the possible protein products of BamHI transcripts of Soybean mosaic virus (SMV, A) and Tobacco vein mottling virus (TVMV, B) in rabbit reticulocyte lysate in vitro translation system. Molecular masses of SMV and TVMV proteins were predicted from amino acid sequences. In vitro transcripts were synthesized from cDNA templates and translated in a rabbit reticulocyte lysate in vitro translation system. Radioactively labeled proteins were analyzed on $8 \%$ polyacrylamide SDS gels. (C) Lane 1: no-template control, 2: BamHI transcripts of SMV (arrows indicate proteins of 35, 43 and $73 \mathrm{kDa}$ ), 3: Bam HI transcripts of TVMV (arrow indicates protein of $70 \mathrm{kDa}$ ). Bars at right represent migrations of prestained protein molecular mass standards.

protein fragments of SMV or TVMV was completely processed in the rabbit reticulocyte lysate system, but more of the TVMV translation products remained unprocessed than those of SMV.

A second set of in vitro translation reactions was performed with SMV and TMV transcripts that included P1, HC-Pro, P3 and portions of the cylindrical inclusion (CI) protein coding regions (Fig. 2, A and B) by cleaving the SMV and TVMV cDNA templates with DraI (position 5386) and XbaI (position 3544), respectively. Translation reactions with DraI transcripts of SMV produced major protein bands of 30, 35, 43, 68 and $80 \mathrm{kDa}$ (Fig. 2C, lane 2). The $35-\mathrm{kDa}$ and $43-\mathrm{kDa}$ protein bands had relative mobilities very similar to the proteins produced from the 
A

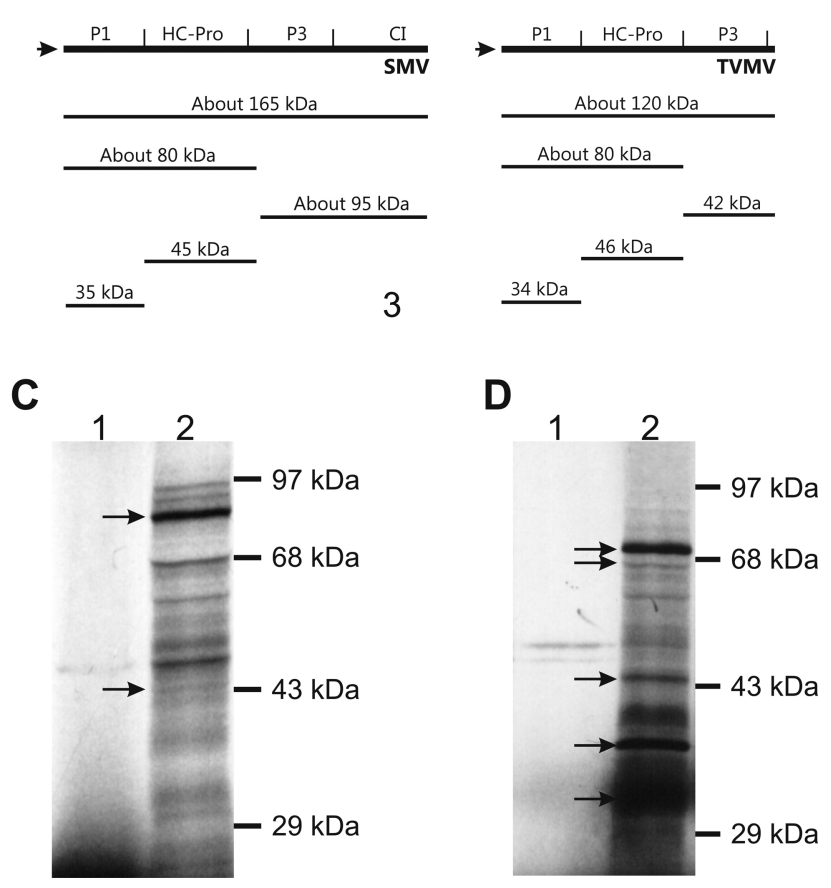

P1 proteases functioned poorly in the rabbit reticulocyte translation system when expressed from in vitro transcripts. Even so, the SMV P1 protease appeared to be somewhat more active than that produced by TVMV. These results for P1 protease activities are similar to those reported for TVMV and Tobacco etch virus (TEV) (Gopinath and Rhoads, 1991; Verchot et al., 1991). The reduced activity of P1 proteases in the rabbit reticulocyte lysate could result from either the presence of protease inhibitors or the absence of a factor required for full P1 protease activity.

Furthermore, we directly tested the effects on protease cleavage by P1 and HC-Pros of the two viruses by the addition of soybean trypsin inhibitor to the in vitro translation reactions. Soybean seeds contain about $1.2 \mathrm{mg} / \mathrm{g}$ of soybean trypsin inhibitor (Kim et al., 1985). To test the effects of the protease inhibitor on SMV and TVMV P1 and HC-Pro protease activities, soybean trypsin inhibitor (Sigma, St. Louis, MO, USA) was added to the rabbit reticulocyte lysate reactions to final concentrations of 0.2 , $0.5,1.0$, and $1.2 \mathrm{mg} / \mathrm{ml}$. Then the DraI transcripts of SMV and $X b a \mathrm{I}$ transcripts of TVMV were added individually to reactions and incubated as described above. The DraI transcripts of SMV produced the same series of translation products with and without soybean trypsin inhibitor (data not shown). In contrast, the $X b a \mathrm{I}$ transcripts of TVMV produced a new protein band of about $120-\mathrm{kDa}$ beginning at a concentration of $0.5 \mathrm{mg} / \mathrm{ml}$ soybean trypsin inhibitor (Fig. 3). This $120-\mathrm{kDa}$ protein corresponded to the expected mass for the unprocessed protein produced by TVMV $X b a \mathrm{I}$ transcripts. The observation that the pattern of in vitro translation products produced by TVMV P1 and HC-Pro was altered by the addition of soybean trypsin inhibitor, but not that produced by SMV supports the hypothesis that the proteases of SMV and TVMV are differentially sensitive to protease inhibitors. Because P1 and HC-Pro are required for multiple functions in the virus life cycle (Plisson et al., 2003), tissue-specific loss of activity of one or more proteases could limit the spread of the virus into or out of those tissues.

In related studies, García et al. (1993) and Wen et al.

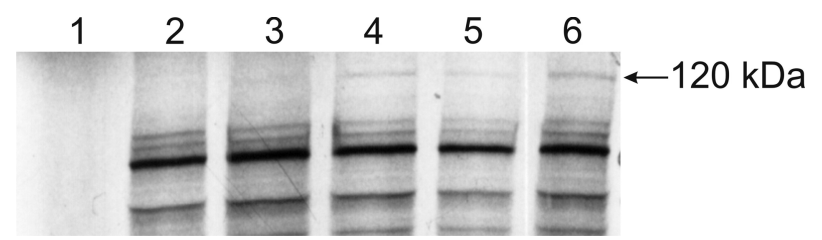

Fig. 3. In vitro processing of $X b a \mathrm{I}$ transcripts of Tobacco vein mottling virus (TVMV) with soybean trypsin inhibitor. Lane 1: no-template control, lanes 2-6: $X b a \mathrm{I}$ transcripts of TVMV with soybean trypsin inhibitor added to final concentrations of $0.0,0.2$, $0.5,1.0$, and $1.2 \mathrm{mg} / \mathrm{ml}$, respectively. Arrow indicates $120 \mathrm{kDa}$ protein band. 
(2004) showed that cystatins, inhibitors of papain-like cysteine proteases, slightly inhibited the activity of Plum pox virus (PPV) HC-Pro, but had very little or no effect on the activity of PPV NIa protease. The TEV NIa protease also was resistant to inhibition by a wide range of protease inhibitors (Dougherty et al., 1989). Similar to the results reported here for soybean trypsin inhibitor and TVMV, high concentrations of cystatins were required to produce low levels of inhibition of PPV HC-Pro, limiting the usefulness of the selected protease inhibitors as antiviral agents. The apparent inhibition of TVMV HC-Pro by soybean trypsin inhibitor is surprising because potyviral HC-Pros have been described as true cysteine proteases that are related to papain (Maia et al., 1996) and soybean trypsin inhibitor typically does not inhibit the activities of papain-like cysteine proteases (Yamamoto and Ikenaka, 1967). It is also possible that the activity of TVMV HC-Pro was more sensitive than SMV HC-Pro to the addition of high levels of exogenous proteins to the in vitro translation reactions.

Protease inhibitors have proven to be valuable tools in managing some of the most recalcitrant human virus diseases (De Clercq, 2004). The often successful management of Human immunodeficiency virus infections with a combination of protease inhibitors is especially noteworthy (Ray et al., 2010). Protease inhibitors also have shown promise for the treatment of chronic Hepatitis $C$ virus infections (Kronenberger and Zeuzem, 2009). The work with human diseases illustrates that the selection of a highly effective protease inhibitor with low toxicity is essential for successful antiviral treatments. Hence, it may be possible to use protease inhibitors to provide resistance to viruses in plants through the careful evaluation and selection of highly effective protease inhibitors.

\section{Acknowledgement}

This work was supported by a grant from the Next-Generation Biogreen 21 Program (PJ008603), Rural Development Administration, Republic of Korea.

\section{References}

Adams, M. J., Antoniw, J. F. and Beaudoin, F. 2005. Overview and analysis of the polyprotein cleavage sites in the family Potyviridae. Mol. Plant Pathol. 6:471-487.

Adams, M. J., Zerbini, F. M., French, R., Rabenstein, F., Stenger, D. C. and Valkonen, J. P. T. 2012. Potyviridae. In: Virus Taxonomy -Classification and Nomenclature of Viruses: Ninth Report of the International Committee on Taxonomy of Viruses, ed. by A. M. Q. King, M. J. Adams, E. B. Carstens and E. J. Lefkowitz. Elsevier Academic Press, Ney York.

Botella, M. A., Xu, Y., Prabha, T. N., Zhao, Y., Narasimhan, M.
L., Wilson, K. A., Nielsen, S. S., Bressan, R. A. and Hasegawa, P. M. 1996. Differential expression of soybean cysteine proteinase inhibitor genes during development and in response to wounding and methyl jasmonate. Plant Physiol. 112:12011210.

Carrington, J. C. and Dougherty, W. G. 1987. Small nuclear inclusion protein encoded by a plant potyvirus genome is a protease. J. Virol. 61:2540-2548.

De Clercq, E. 2004. Antivirals and antiviral strategies. Nat. Rev. Microbiol. 2:704-720.

Domier, L. L., Franklin, K. M., Hunt, A. G., Rhoads, R. E. and Shaw, J. G. 1989. Infectious in vitro transcripts from cloned cDNA of a potyvirus, tobacco vein mottling virus. Proc. Natl. Acad. Sci. USA 86:3509-3513.

Dougherty, W. G., Parks, T. D., Cary, S. M., Bazan, J. F. and Fletterick, R. J. 1989. Characterization of the catalytic residues of the tobacco etch virus 49-kDa proteinase. Virology 172:302310 .

García, J. A., Cervera, M. T., Riechmann, J. L. and López-Otín, C. 1993. Inhibitory effects of human cystatin $C$ on plum pox potyvirus proteases. Plant Mol. Biol. 22:697-701.

Gopinath, M. and Rhoads, R. E. 1991. In vitro cleavage at or near the N-terminus of the helper component protein in the tobacco vein mottling virus polyprotein. Virology 185:721-731.

Hill, J. H. 1999. Soybean Mosaic Virus. In: Compendium of Soybean Diseases, ed. by G. L. Hartman, J. B. Sinclair and J. C. Rupe. The American Phytopathological Society, St. Paul, MN.

Kim, S. H., Hara, S., Hase, S., Ikenaka, T., Toda, H., Kitamura, K. and Kaizuma, N. 1985. Comparative study on amino acid sequences of kunitz-type soybean trypsin Inhibitors, Tia, Tib, and Tic. J. Biochem. 98:435-448.

Koiwa, H., Bressan, R. A. and Hasegawa, P. M. 1997. Regulation of protease inhibitors and plant defense. Trends Plant Sci. 2:379-384.

Kronenberger, B. and Zeuzem, S. 2009. Current and future treatment options for HCV. Ann. Hepatol. 8:103-112.

Laskowski, M. and Kato, I. 1980. Protein inhibitors of proteinases. Annu. Rev. Biochem. 49:593-626.

Maia, I. G., Haenni, A. L. and Bernardi, F. 1996. Potyviral HCPro: a multifunctional protein. J. Gen. Virol. 77:1335-1341.

Plisson, C., Drucker, M., Blanc, S., German-Retana, S., Le Gall, O., Thomas, D. and Bron, P. 2003. Structural characterization of HC-Pro, a plant virus multifunctional protein. J. Biol. Chem. 278:23753-23761.

Ray, S., Fatima, Z. and Saxena, A. 2010. Drugs for AIDS. Mini Rev. Med. Chem. 10:147-161.

Sun, M. K. C., Gooding, G. V., Pirone, T. P. and Tolin, S. A. 1974. Properties of tobacco vein-mottling virus, a new pathogen of tobacco. Phytopathology 64:1133-1136.

Tan-Wilson, A. L., Hartl, P. M., Delfel, N. E. and Wilson, K. A. 1985. Differential expression of Kunitz and Bowman-Birk Soybean proteinase-inhibitors in plant and callus tissue. Plant Physiol. 78:310-314.

Verchot, J., Koonin, E. V. and Carrington, J. C. 1991. The 35-kDa protein from the $\mathrm{N}$-terminus of the potyviral polyprotein functions as a third virus-encoded proteinase. Virology 185:527- 
535.

Walling, L., Drews, G. N. and Goldberg, R. B. 1986. Transcriptional and post-transcriptional regulation of soybean seed protein mRNA levels. Proc. Natl. Acad. Sci. USA 83:2123-2127.

Wen, R., Zhang, S. C., Michaud, D. and Sanfaçon, H. N. 2004. Inhibitory effects of cystatins on proteolytic activities of the
Plum pox potyvirus cysteine proteinases. Virus Res. 105:175182.

Yamamoto, M. and Ikenaka, T. 1967. Studies on soybean trypsin inhibitors: I. purification and characterization of 2 soybean trypsin inhibitors. J. Biochem. 62:141-149. 